\title{
PEMETAAN REKOMENDASI PENGELOLAAN KAWASAN TAMAN NASIONAL GUNUNG MERAPI DARI POTENSI ANCAMAN PERAMBAHAN
}

\author{
Arinalhaq ${ }^{1}$, Totok Wahyu Wibowo ${ }^{2}$ \\ 1Program Penginderaan Jauh dan SIG, Sekolah Vokasi, Universitas Gadjah Mada \\ Jalan Sekip Utara No 1 Catur Tunggal, Depok Sleman, 55281, Yogyakarta, Indonesia \\ 2Dept. Sains Informasi Geografi, Fakultas Geografi, Universitas Gadjah Mada \\ Jalan Kaliurang, Sekip Utara, Bulaksumur Sinduadi Sleman, 55281, Yogyakarta, Indonesia \\ e-mail: totok.wahyu@ugm.ac.id
}

\begin{abstract}
Abstrak
Kawasan Taman Nasional Gunung Merapi (TNGM) memiliki ragam potensi keunikan keanekaragaman hayati, alam, budaya dan sosial ekonomi, sehingga keberadaan kawasan ini penting dalam menciptakan hubungan yang berkelanjutan antara manusia dan lingkungan alam. Ancaman akan kelestarian TNGM salah satunya datang dari kegiatan perambahan yang dilakukan oleh manusia. Penelitian ini bertujuan untuk menyusun peta tingkat potensi perambahan di TNGM dengan menggnakan pemodelan spasial berbasis Sistem Informasi Geografis (SIG). Pengetahuan tentang tingkat potensi perambahan tersebut dapat dimanfaatkan untuk mengetahui distribusi wilayah yang perlu disarankan untuk tindakan pengawasan. Pemodelan potensi ancaman perambahan disusun berdasarkan parameter ketinggian tempat, kemiringan lereng, jarak dari jaringan jalan, jarak dari jaringan sungai, jarak dari penggunaan lahan, dan jarak dari permukiman. Proses analisis yang digunakan adalah analisis tumpang susun dengan menggunakan metode kuantitatif berjenjang tertimbang. Hasil pemetaan potensi ancaman kemudian diintegrasikan dengan peta zonasi kawasan untuk menghasilkan rekomendasi tindakan pengawasan. Berdasarkan peta potensi ancaman diketahui bahwa bagian selatan dari daerah kajian memiliki tingkat ancaman yang paling tinggi, yang mana merupakan daerah di sekitar batas TNGM. Analisis rekomendasi tindakan pengawasan menunjukkan bahwa terdapat 1.194,71 hektar (58.35\%) dari daerah kajian disarankan untuk diawasi. Daerah tersebut memiliki nilai potensi ancaman perambahan yang relatif tinggi dan termasuk dalam Zona Inti. Tepatnya berada dekat dengan batas kawasan yang kemungkinan besar terpengaruh oleh aktivitas masyarakat.
\end{abstract}

Kata kunci: TNGM, Potensi Ancaman Perambahan, Sistem Informasi Geografis, Pemodelan Spasial.

\begin{abstract}
Mount Merapi National Park (TNGM) has a variety of potential uniqueness of biodiversity, nature, culture and socio-economic. The existence of this region is critical in creating sustainable relationships between humans and their natural environment. One of the threats to TNGM sustainability comes from encroachment activities carried out by humans. This study aims to perform spatial modeling by utilizing Geographic Information System to produce potential encroachment level map and uncover the areas that need monitoring. There are six parameters used to develop an encroachment threat model, namely elevation, slope, distance from the road, distance from the hydrological network, distance from land use, and distance from the settlement. Overlay analysis was implemented using a quantitative weighted scoring method. The result is then integrated with the TNGM zonation map to produce recommendations for supervision actions. The map of the potential level of encroachment threat show there are five classes of threat varying from high to low. The high-threat spatial arrangement dominates the southern area which is around the TNGM boundary. Recommendation analysis of supervisory actions shows that
\end{abstract}


there are 1194.71 hectares (58.35\%) of the study area recommended being monitored. Those were the region that both have a relatively high potential threat of encroachment and settled in the Core Zone. Precisely located near the boundaries of the area which are commonly affected by community activities.

Key words: TNGM, Potential encroachment threat, Geographic Information System, Spatial modelling.

\section{PENDAHULUAN}

Indonesia memiliki Kawasan Suaka Alam dan Kawasan Perlindungan Alam seluas 23 ribu hektar, yang mana $65 \%$ dari area tersebut merupakan taman nasional (PHKA, 2008). Sebesar 30\% taman tasional di Indonesia yang berada di darat mengalami kerusakan akibat beberapa hal seperti perambahan, pembalakan liar, dan kebakaran hutan (Kompas, 2012). Hal tersebut tidak lepas dari kebutuhan masyarakat yang berpotensi menyebabkan terganggunya fungsi kawasan taman nasional. Salah satu taman nasional yang terletak di Pulau Jawa yaitu Taman Nasional Gunung Merapi (TNGM) yang secara administratif berada di Kabupaten Magelang, Kabupaten Boyolali, dan Kabupaten Klaten di Provinsi Jawa Tengah, serta Kabupaten Sleman di Daerah Istimewa Yogyakarta.

Pada konteks ekosistem, kawasan TNGM merupakan lingkungan kompleks yang tersusun atas komponen abiotik, biotik, dan budaya. Masing-masing komponen berinteraksi secara kompleks dan membangun harmonisasi fungsi dan sistem tata kehidupan. Terganggunya fungsi salah satu aspek dari komponen lingkungan akan berdampak pada ketidakteraturan fungsi dari seluruh komponen lingkungan penyusunnya (Darmawan, 2016).

Secara umum ancaman di TNGM dapat dibedakan menjadi dua, yaitu ancaman alamiah dan ancaman akibat aktivitas manusia. Ancaman alamiah berasal dari aktivitas vulkanik Gunung Merapi, yang merupakan salah satu gunung berapi di Indonesia yang masih aktif. Ancaman aktivitas manusia yang terjadi di kawasan TNGM diantaranya penambangan pasir, daerah yang rawan perambahan. Pemetaan potensi ancaman fungsi kawasan di Taman perumputan, hingga pembukaan lahan untuk budidaya rumput pada kawasan hutan.

Karakteristik masyarakat yang beragam, berdampak pada bentuk ancaman yang bervariasi di setiap wilayah administrasi. Masyarakat Turi misalnya, hampir seluruhnya adalah petani salak yang cukup mengangkat perekonomian masyarakat. Tetapi perkembangan pertanian salak juga memberikan dampak buruk yaitu banyaknya lahan yang dikonversi menjadi lahan salak.

Kecamatan Pakem merupakan salah satu destinasi wisata di Yogyakarta. Perkembangan pariwisata yang cukup pesat dapat menyebabkan konversi lahan menjadi lahan terbangun. Sementara itu sebagian besar masyarakat Cangkringan bergantung pada kegiatan peternakan, terutama sapi perah. Kebutuhan untuk pakan ternak melibatkan perambahan perumputan yang yang berada di sekitar TNGM. Disamping peternak sapi, masyarakat Cangkringan juga berantung pada penambangan pasir.

Faktor-faktor yang menjadi penyebab adanya perambahan di kawasan konservasi khususnya kawasan hutan yaitu faktor kepadatan penduduk yang tinggi, faktor ekonomi, faktor hubungan luar, akses menuju kawasan, keterbatasan pengawasan, faktor pendidikan serta belum optimalnya informasi tentang batas pemanfaatan kawasan (Djajono, 2009; Putikasari dkk., 2014). Salah satu upaya untuk menjaga keutuhan dan perlindungan sumberdaya alam di TNGM yaitu dengan cara mengetahui daerah yang berpotensi mengancam fungsi kawasan sehingga pengelolaan dapat dilaksanakan secara terarah dan lebih intensif pada daerah-

Nasional Gunung Merapi dapat diketahui melalui analisis spasial dengan 
memanfaatkan Sistem Informasi Geografis. Lebih lanjut, peta tersebut dapat dimanfaatkan untuk rekomendasi tindakan yang harus dilakukan pada kawasan taman nasional mengacu pada zonasi kawasan taman nasional.

Analisis buffer pernah digunakan oleh beberapa peneliti untuk memetakan parameter aktivitas masyarakat di kawasan konservasi (Mulyanto, 2004; Purba, 2010; Yuniarsih, dkk., 2014; Marhaento dan Rahayu, 2015). Kombinasi dengan parameter lain dapat dilakukan dengan analisis tumpang susun (overlay). Eksplorasi faktor lain yang menyesuaikan kondisi area kajian perlu dilakukan untuk meningkatkan ketepatan model yang dibangun.

\section{METODE PENELITIAN \\ Lokasi Penelitian}

Penelitian ini dilaksanakan di kawasan Taman Nasional Gunung Merapi bagian Kabupaten Sleman, Daerah Istimewa Yogyakarta. Kawasan TNGM di DIY mencangkup 7 desa/kelurahan, yaitu Girikerto dan Wonokerto di Kecamatan Turi, Purwobinangun dan Hargobinangun di Kecamatan Pakem, Umbulharjo, Kepuharjo dan Glagahrejo di Kecamatan Cangkringan, Kabupaten Sleman (Gambar 1).

Kawasan TNGM di Yogyakarta ini dipilih karena kawasan hutannya masih cukup baik namun memiliki ancaman perambahan di sekitar kawasan. Fungsi kawasan sebelum ditunjuk menjadi TNGM di wilayah DIY terdiri dari Hutan Lindung (HL) seluas 1.041,38 ha; Cagar Alam (CA) Plawangan Turgo seluas 146,16 ha; dan Taman Wisata Alam (TWA) Plawangan Turgo 96,45 ha.

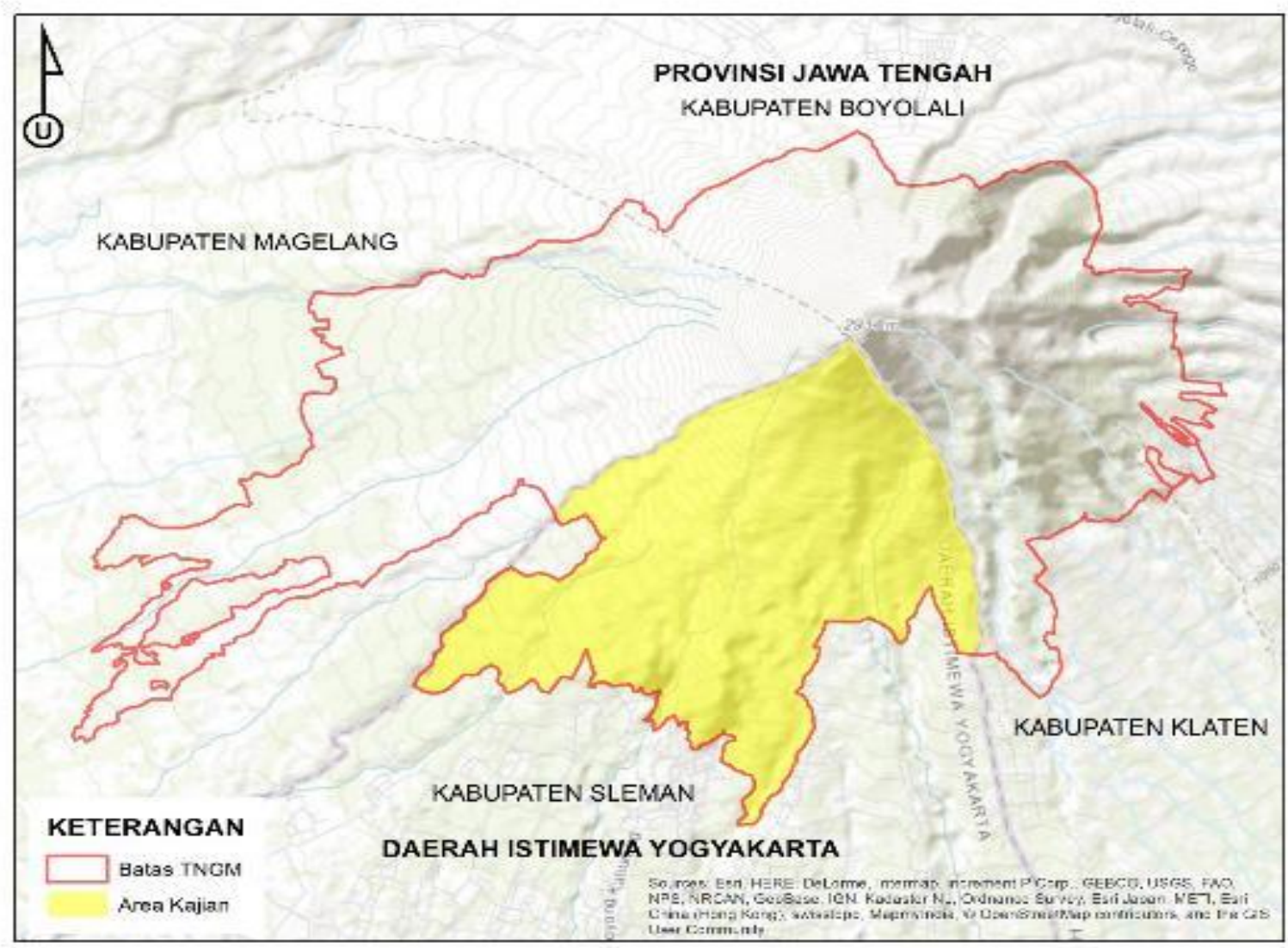

Gambar 1. Warna kuning menunjukkan lokasi kajian, di Kabupaten Sleman 
Parameter untuk Potensi Ancaman Perambahan

Penyusunan parameter dalam pembuatan peta tingkat potensi ancaman perambahan di Sebagian Kawasan TNGM disesuaikan dengan kondisi yang terjadi di daerah penelitian. Parameter tersebut meliputi ketinggian tempat (elevasi), kemiringan lereng, jarak terhadap jaringan jalan, jarak terhadap jaringan sungai, jarak terhadap penggunaan lahan, dan jarak terhadap permukiman.

Peta kontur dari peta Rupabumi Indonesia (RBI) skala 1:25.000 digunakan sebagai dasar untuk penyusunan peta ketinggian tempat, yang kemudian dapat diturunkan menjadi peta kemiringan lereng. Peta penggunaan lahan diperoleh dengan cara melakukan pembaruan data penggunaan lahan tahun 2005. Citra Quickbird tahun 2014 digunakan sebagai dasar untuk pembaruan data penggunaan lahan tersebut. Proses pembaruan dilakukan dengan cara interpretasi visual. Data jaringan jalan dan jaringan sungai diperoleh dari peta RBI skala 1:25.000. Analisis buffer dilakukan kedua pada data tersebut untuk mendapatkan kelas jarak dari setiap data.

Pengaruh setiap parameter penentu potensi ancaman perambahan diwakilkan dengan pemberian nilai bobot tiap parameter (Tabel 1). Penentuannya dilakukan secara subjektif berdasarkan rujukan pada penelitian sebelumnya (Purba, 2010). Namun, yang membedakan adalah adanya penambahan parameter jarak penggunaan lahan. Hal ini disebabkan karena penggunaan lahan juga memiliki kontribusi yang cukup signifikan dalam penentuan potensi ancaman perambahan berdasarkan analisis laporan rencana kerja oleh Rakhmawati (2008). Dalam hal ini terdapat dua jenis penggunaan lahan yang berpotensi menerima ancaman perambahan, yaitu padang rumput dan tegalan.

\section{Penyusunan Peta Potensi Ancaman Perambahan}

Analisis tumpangsusun digunakan untuk menggabungkan keenam parameter yang telah disebutkan. Skor total didapatkan dari hasil penjumlahan skor pada setiap parameter, yang sebelumnya telah dikalikan dengan bobot (Persamaan 1). Hasil penjumlahan skor tersebut selanjutnya diklasifikasikan untuk menentukan tingkat potensi ancaman perambahan.

Tabel 1. Skor parameter potensi ancaman perambahan

\begin{tabular}{|c|c|c|}
\hline \multicolumn{3}{|c|}{ Elevasi } \\
\hline Bobot & Elevasi (mdpl) & Skor \\
\hline \multirow{5}{*}{5} & $0-500$ & 10 \\
\hline & $500-1.000$ & 7 \\
\hline & $1.000-1.500$ & 5 \\
\hline & $1.500-2.000$ & 3 \\
\hline & $>2.000$ & 1 \\
\hline \multicolumn{3}{|c|}{ Kemiringan Lereng } \\
\hline Bobot & Kemiringan (\%) & Skor \\
\hline \multirow{5}{*}{3} & $0-8$ & 10 \\
\hline & $8-15$ & 7 \\
\hline & $15-25$ & 5 \\
\hline & $25-40$ & 3 \\
\hline & $>40$ & 1 \\
\hline \multicolumn{3}{|c|}{ Jarak Terhadap Jalan } \\
\hline Bobot & Jarak (m) & Skor \\
\hline \multirow{6}{*}{10} & $0-200$ & 10 \\
\hline & $200-400$ & 8 \\
\hline & $400-600$ & 7 \\
\hline & $600-800$ & 5 \\
\hline & $800-1.000$ & 3 \\
\hline & $>1.000$ & 2 \\
\hline \multicolumn{3}{|c|}{ Jarak Terhadap Sungai } \\
\hline Bobot & Jarak (m) & Skor \\
\hline \multirow{6}{*}{2} & $0-200$ & 10 \\
\hline & $200-400$ & 8 \\
\hline & $400-600$ & 7 \\
\hline & $600-800$ & 5 \\
\hline & $800-1.000$ & 3 \\
\hline & $>1.000$ & 2 \\
\hline \multicolumn{3}{|c|}{ Jarak Terhadap Penggunaan Lahan } \\
\hline Bobot & Jarak (m) & Skor \\
\hline \multirow{6}{*}{20} & $0-200$ & 10 \\
\hline & $200-400$ & 8 \\
\hline & $400-600$ & 7 \\
\hline & $600-800$ & 5 \\
\hline & $800-1.000$ & 3 \\
\hline & $>1.000$ & 2 \\
\hline \multicolumn{3}{|c|}{ Jarak Terhadap Permukiman } \\
\hline Bobot & Jarak (m) & Skor \\
\hline \multirow{6}{*}{20} & $0-200$ & 10 \\
\hline & $200-400$ & 8 \\
\hline & $400-600$ & 7 \\
\hline & $600-800$ & 5 \\
\hline & $800-1.000$ & 3 \\
\hline & $>1.000$ & 2 \\
\hline
\end{tabular}

Sumber: Purba (2010) dengan penambahan

$\mathrm{ST}=5(\mathrm{E})+3(\mathrm{~L})+10(\mathrm{~J})+2(\mathrm{~S})+20(\mathrm{P})+20(\mathrm{M}) \ldots(1)$ 
Keterangan:

ST $=$ Skor total

$\mathrm{E}=$ Skor elevasi

$\mathrm{L}=$ Skor kemiringan lereng

$\mathrm{J}=$ Skor jarak terhadap jalan

$\mathrm{S}=$ Skor jarak terhadap sungai

$\mathrm{P}=$ Skor jarak terhadap penggunaan lahan

$\mathrm{M}=$ Skor jarak terhadap permukiman

Kelas tingkat potensi ancaman dibagi menjadi lima kelas yaitu rendah, agak rendah, sedang, agak tinggi, dan tinggi. Klasifikasi tersebut ditentukan berdasarkan metode natural breaks dimana fitur dibagi menjadi kelas yang batasnya ditentukan karena terdapat perbedaan nilai data yang relatif besar. Natural breaks merupakan metode klasifikasi data spesifik yang baik digunakan untuk pemetaan nilai yang tidak merata (Crisana, 2014).

Pada hasil analisis peta potensi ancaman perambahan dilakukan plotting lokasi kejadian perambahan yang pernah terjadi di sebagian kawasan TNGM. Hal ini dimaksudkan sebagai pembanding antara hasil analisis tingkat potensi ancaman perambahan dengan titik kejadian perambahan yang pernah terjadi di daerah kajian.

\section{Penyusunan Area Rekomendasi}

Rekomendasi strategi pengurangan tingkat perambahan dihasilkan dengan cara melakukan analisis tumpangsusun antara peta tingkat potensi ancaman perambahan kawasan dengan peta zonasi kawasan. Peta ini memberikan informasi rekomendasi pengawasan pada tingkatan potensi perambahan kawasan. Secara umum, rekomendasi akan dibagi menjadi dua, yaitu area yang diawasi dan area yang tidak diawasi. Sebagai contoh, jika terdapat area dengan ancaman perambahan tingkat tinggi yang terdapat di zona inti, maka pada wilayah tersebut perlu adanya pengawasan. Wilayah kawasan taman nasional dengan ancaman perambahan tinggi di zona pemanfaatan, dapat direkomendasikan tindakan pengawasan untuk mewaspadai jika perambahan meluas pada wilayah zona yang dilindungi.

Wilayah dengan potensi perambahan tingkat sedang pada setiap zona berbeda dalam rekomendasi tindakan pengawasannya. Zona inti, zona rimba, zona rehabilitasi, zona religi, budaya, dan sejarah, serta zona khusus mitigasi dan rekonstruksi pada potensi perambahan tingkat sedang masih perlu adanya pengawasan karena wilayah ini merupakan wilayah dengan perlindungan yang ketat. Sedangkan zona pemanfaatan dan zona tradisional pada potensi perambahan tingkat sedang tidak direkomendasi dilakukannya pengawasan begitu pula pada wilayah kawasan taman nasional dengan potensi perambahan tingkat agak rendah dan rendah yang juga tidak direkomendasi dilakukannya pengawasan. Berikut informasi rekomendasi tindakan pengawasan terhadap tingkat potensi ancaman perambahan di sebagian kawasan Taman Nasional Gunung Merapi yang dapat ditunjukkan pada Tabel 2, sementara itu metode penelitian disajikan pada Gambar 2.

Tabel 2. Rekomendasi tindakan pengawasan terhadap potensi ancaman perambahan

\begin{tabular}{|l|c|c|c|c|c|}
\hline \multirow{2}{*}{ Zona } & \multicolumn{5}{|c|}{ Tingkat Potensi } \\
\cline { 2 - 6 } & T & AT & S & AR & R \\
\hline Inti & D & D & D & TD & TD \\
\hline Rimba & D & D & D & TD & TD \\
\hline Pemanfaatan & D & D & TD & TD & TD \\
\hline Tradisional & D & D & TD & TD & TD \\
\hline Rehabilitasi & D & D & D & TD & TD \\
\hline $\begin{array}{l}\text { Religi, Budaya, dan } \\
\text { Sejarah }\end{array}$ & D & D & D & TD & TD \\
\hline Khusus & D & D & D & TD & TD \\
\hline
\end{tabular}

Keterangan $=\mathrm{T}$ : Tinggi, AT: Agak tinggi, S: Sedang, AR: Agak rendah, R: Rendah, D: Diawasi, TD: Tidak diawasi. 


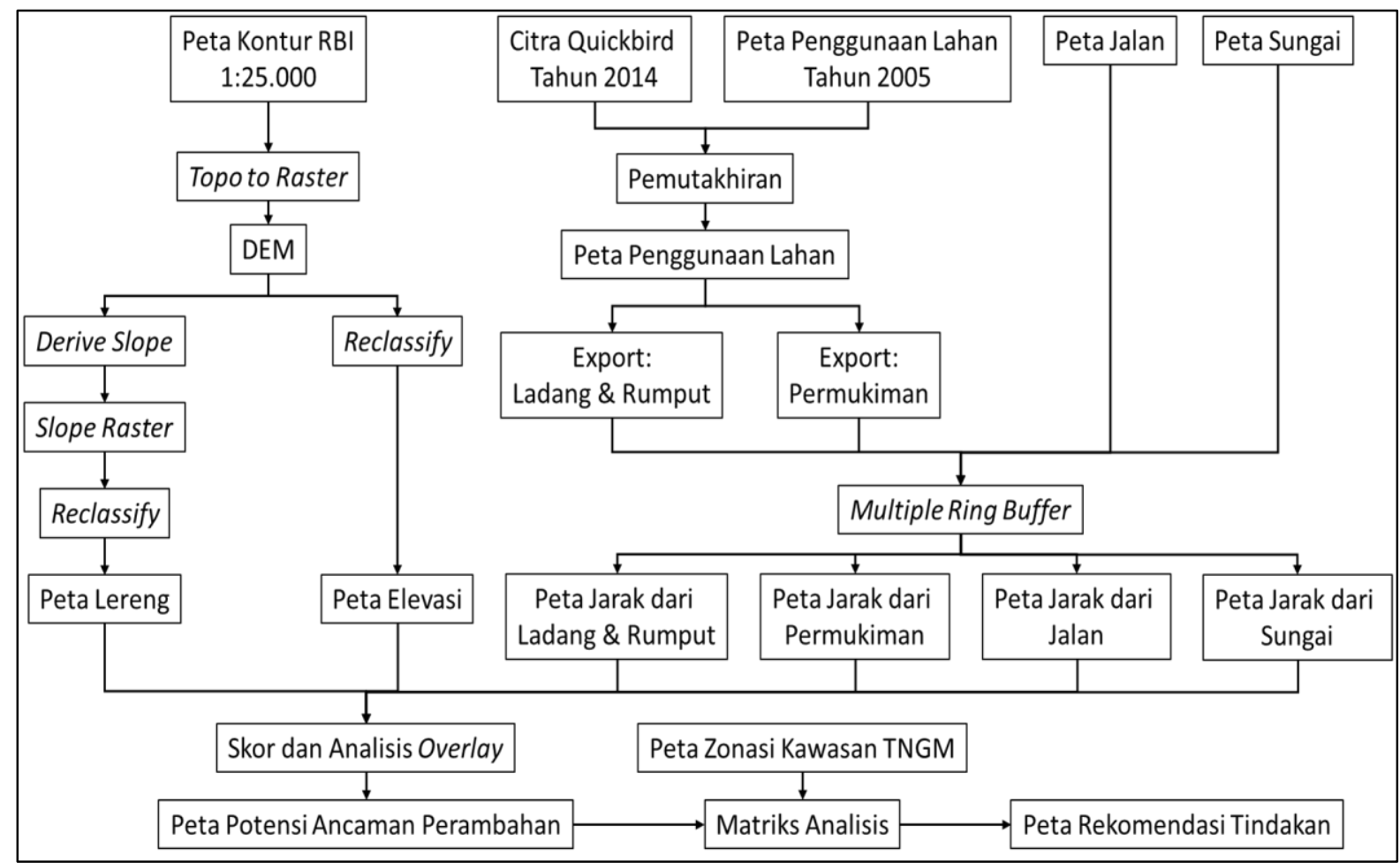

Gambar 2. Diagram alir penelitian

\section{HASIL DAN PEMBAHASAN \\ Persiapan Parameter}

Elevasi terendah dari lokasi kajian ialah 681,59 mdpl, sehingga hanya terdapat empat kelas ketinggian mengacu pada Tabel 1.1. Kelas ketinggian tempat yang mendominasi daerah kajian yaitu antara 1000 - 1500 mdpl dengan luasan sebesar $61,55 \%$ dari total luas daerah penelitian (Gambar 3a). Daerah dengan ketinggian tempat yang lebih rendah memiliki tingkat potensi ancaman perambahan lebih tinggi dibandingkan daerah dengan ketinggian tempat yang lebih tinggi. Hal ini disebabkan daerah dengan ketinggian tempat yang rendah lebih mudah dijangkau oleh masyarakat untuk diambil sumber daya alamnya dibanding daerah dengan ketinggian tempat yang lebih tinggi.

Kelas kemiringan $>40 \%$ mendominasi daerah penelitian dengan persentase mencapai 55,54 \% (Gambar 3b). Kelas ini merupakan kelas dengan tingkat potensi ancaman paling rendah karena masyarakat lebih jarang melakukan aktifitas di daerah dengan kemiringan yang relatif curam. Sebaliknya lereng yang datar/landai (0 - 8 $\%)$ hanya terdapat sebesar 2,96 \%. Kelas kemiringan ini merupakan kelas dengan tingkat potensi ancaman paling tinggi karena daerah ini lebih mudah dicapai oleh masyarakat untuk dilakukan perambahan.

Hasil pemutakhiran penggunaan lahan menunjukkan bahwa sawah irigasi dan kebun mendominasi wilayah kajian (Gambar 3c). Penggunaan lahan dari tahun 2005 hingga tahun 2014 memiliki penambahan penggunaan lahan berupa pasir darat seluas 408,89 ha yang diinterpretasi dari warna yang keabu-abuan, bertekstur halus, dan terdapat di sekitar sungai. Perubahan luas penggunaan lahan paling besar terjadi pada penggunaan lahan berupa belukar/semak, yang mengalami penurunan luas sekitar 1.114,66 ha. Sebagian besar penggunaan lahan belukar/semak berubah menjadi hutan dengan luas 457,64 ha dan rumput dengan luas 304,49 ha. Di sisi lain, penggunaan lahan kebun mengalami peningkatan luas sebesar 1.106,95 ha. Perubahan penggunaan lahan kebun dari tahun 2014 sebagian besar berasal dari penggunaan lahan berupa tegalan pada tahun 2005. 

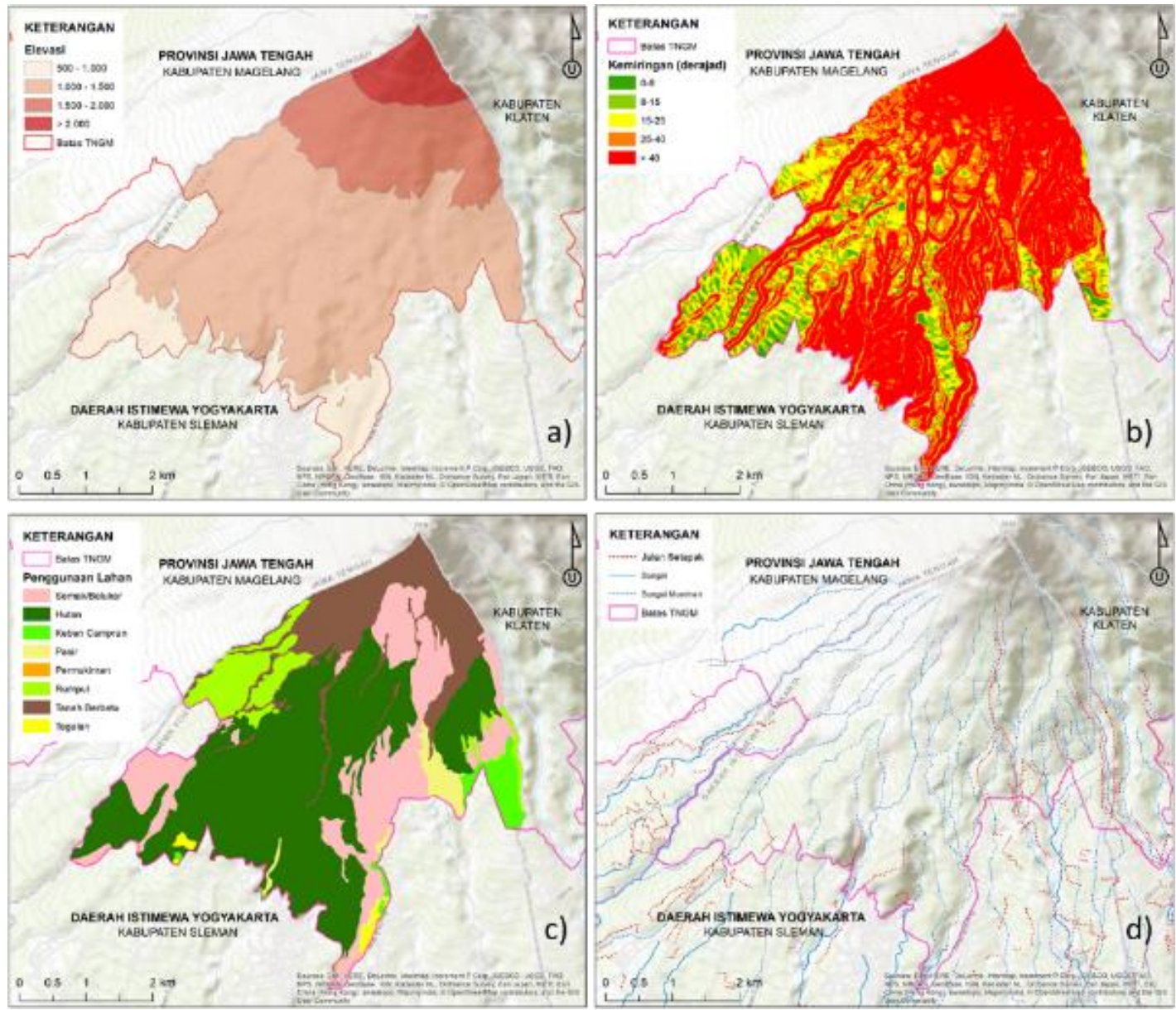

Gambar 3. a) Peta elevasi, b) peta kemiringan lereng, c) peta penggunaan lahan, dan d) peta jaringan jalan dan sungai

\section{Potensi Perambahan Lahan}

Gambar 4 menunjukkan distribusi tingkat potensi ancaman perambahan dan distribusi titik kejadian perambahan yang pernah terjadi. Kelas tingkat potensi ancaman perambahan yang mendominasi daerah penelitian yaitu kelas potensi sedang dengan luasan sebesar 540,49 ha atau 26,4\% dari total luas daerah penelitian. Sementara itu kelas tingkat potensi ancaman perambahan dengan luasan terkecil yaitu kelas potensi tinggi dengan luasan sebesar 307,98 ha atau $15,04 \%$ dari total luas daerah penelitian. Data luasan secara lengkap dapat dilihat pada Tabel 3.

Kelas potensi ancaman perambahan di sebagian kawasan TNGM mulai dari tinggi ke rendah terdistribusi dari selatan ke utara. Kelas potensi agak rendah dan potensi rendah sebagian besar terdistribusi di bagian tengah hingga puncak Gunung Merapi. Sementara itu kelas potensi agak tinggi dan potensi tinggi sebagian besar terdistribusi di bagian selatan dekat dengan batas kawasan. Berdasarkan hasil analisis model yang dibuat untuk pemetaan tingkat potensi ancaman perambahan, sejatinya sudah sesuai dengan teori bahwa semakin mendekati batas kawasan maka tingkat ancamannya semakin tinggi.

Tabel 3. Luas Tingkat Potensi Ancaman Perambahan Di Sebagian Kawasan Taman Nasional Gunung Merapi

\begin{tabular}{lllr}
\hline No & $\begin{array}{c}\text { Tingkat Potensi } \\
\text { Ancaman } \\
\text { Perambahan }\end{array}$ & $\begin{array}{l}\text { Luas } \\
\mathbf{( H a )}\end{array}$ & $\begin{array}{c}\text { Luas } \\
\mathbf{( \% )}\end{array}$ \\
\hline 1. & Rendah & 457,19 & 22,33 \\
\hline 2. & Agak Rendah & 321,36 & 15,69 \\
\hline 3. & Sedang & 540,49 & 26,40 \\
\hline 4. & Agak Tinggi & 420,56 & 20,54 \\
\hline 5. & Tinggi & 307,98 & 15,04 \\
\hline Jumlah & $\mathbf{2 . 0 4 7 , 5 8}$ & $\mathbf{1 0 0}$ \\
\hline
\end{tabular}


Data kejadian perambahan yang pernah terjadi di sebagian kawasan TNGM didapatkan dari beberapa sumber seperti data statistik, data perumputan, maupun dari wawancara narasumber secara langsung. Titik-titik kejadian perambahan di sebagian kawasan TNGM terdapat di beberapa blok seperti Blok Klangon, Blok Kemloso, Blok Dlimas, Blok Belik Cemoro, Blok Sembung, Blok Empat Puluhan, Blok Pathuk, dan Blok Tritis.

Kejadian perambahan yang terjadi di Blok Klangon diantaranya pengarangan, perumputan, dan perburuan satwa (burung). Pada Blok Dlinar dan Blok Kemloso terdapat kejadian perambahan berupa perburuan satwa (burung) dan perumputan. Kedua ancaman tersebut juga ditemui di Blok Belik Cemoro dengan tambahan ancaman berupa perencekan kayu. Kejadian perambahan di Blok Sembung lebih pada kejadian perburuan satwa (burung), sedangkan pada Blok Empat Puluhan, Blok Pathuk, dan Blok Tritis didominasi oleh kejadian perumputan.

Sebagian besar data titik kejadian perambahan di kawasan TNGM terletak pada daerah potensi ancaman tingkat tinggi. Hal ini menunjukkan model yang disusun cukup untuk menggambarkan tingkat potensi perambahan sangat tinggi. Di sisi lain terdapat masing-masing satu titik kejadian yang masuk pada kelas potensi perambahan tingkat rendah dan agak rendah. Kedua titik tersebut terletak di Blok Sembung dan Blok Empat Puluhan. Blok Sembung memiliki ancaman berupa perburuan satwa, yang mana hal tersebut tidak dimasukkan sebagai salah satu faktor dalam pemodelan spasial. Sementara itu pada Blok Empat Puluhan terjadi perambahan berupa perumputan yang dapat disebabkan karena wilayah tersebut termasuk zona tradisional yang memiliki fungsi sebagai pemanfaatan tradisional oleh masyarakat namun dengan kesepakatan dan kriteria yang berlaku. Apabila pemanfaatan sudah melewati batas atau dapat merugikan kawasan TNGM, maka wilayah tersebut perlu adanya pengawasan yang lebih.

Wilayah dengan potensi ancaman perambahan tingkat agak tinggi hingga tinggi menjadi wilayah yang perlu diwaspadai. Wilayah ini sebagian besar terletak pada bagian selatan kawasan TNGM tepatnya dekat dengan batas kawasan yang masih memiliki pengaruh dari aktivitas masyarakat desa sekitar kawasan. Distribusi tingkatan potensi ancaman perambahan dan historis kejadian perambahan dapat dilihat secara garis besar pada peta tingkat potensi ancaman perambahan di sebagian kawasan Taman Nasional Gunung Merapi.

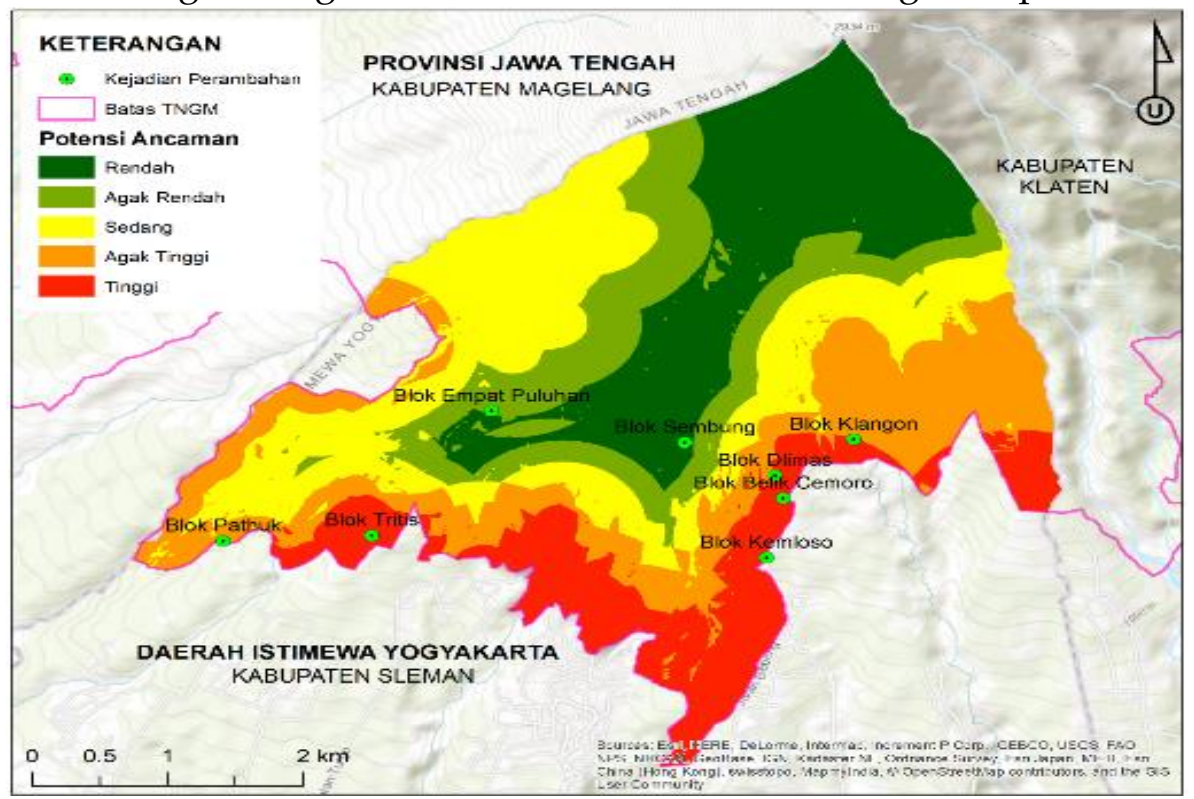

Gambar 4. Potensi ancaman perambahan di area kajian 


\section{Area Rekomendasi Tindakan}

Peta rekomendasi tindakan terhadap tingkat potensi ancaman perambahan di sebagian kawasan Taman Nasional Gunung Merapi menyajikan informasi berupa rekomendasi pengawasan pada tingkatan potensi ancaman perambahan yang dibagi menjadi 2 tindakan yaitu diawasi dan tidak diawasi. Daerah yang diawasi merupakan daerah yang disarankan menjadi perhatian khusus bagi pengelola untuk diberikan pengawasan. Sedangkan daerah yang tidak diawasi merupakan daerah yang cukup aman dari tindakan perambahan oleh masyarakat yang dilihat dari aspek aktivitas manusia dan lingkungannya

Penentuan rekomendasi tindakan dilakukan berdasarkan tingkatan potensi ancaman perambahan terhadap kriteria dan kegiatan yang dapat dilakukan pada zona tertentu di kawasan TNGM yang mengacu pada Permenhut No. P56 Tahun 2006. Wilayah kawasan TNGM dengan potensi ancaman perambahan tingkat agak tinggi dan tingkat tinggi pada semua zonasi kawasan memiliki rekomendasi tindakan berupa perlunya pengawasan. Walaupun berada di wilayah dengan zona pemanfaatan dan tradisional, potensi tingkat tinggi dan agak tinggi pada wilayah ini masih perlu adanya pengawasan karena untuk mewaspadai jika perambahan meluas pada wilayah zona yang dilindungi. Wilayah kawasan TNGM dengan potensi ancaman perambahan tingkat rendah dan agak rendah pada semua zonasi kawasan tidak perlu adanya rekomendasi pengawasan karena wilayah ini masih aman dari tindakan perambahan oleh masyarakat sekitar kawasan.

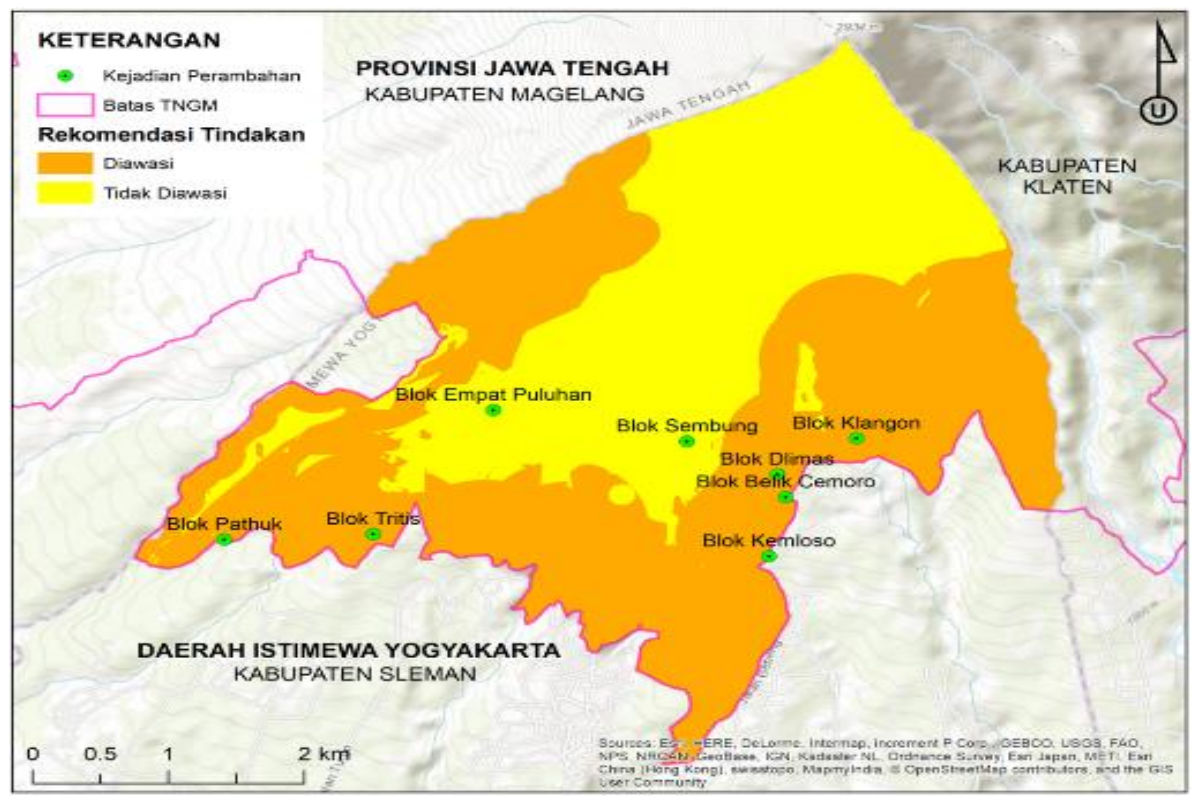

Gambar 5. Peta area rekomendasi tindakan pengawasan

\section{KESIMPULAN}

Berdasarkan hasil analisis spasial yang dilakukan menunjukkan bahwa semakin mendekati batas kawasan maka tingkat ancaman perambahan akan semakin tinggi. Hal tersebut sesuai dengan tinjauan teoritis. Tingkat potensi ancaman perambahan yang paling tinggi sebagian besar terdapat di kawasan TNGM bagian selatan dengan luas sebesar 370,98 ha atau $15,04 \%$ dari total luas daerah penelitian.
Analisis rekomendasi tindakan pencegahan perambahan di TNGM dihasilkan dari peta tingkat ancaman dengan peta zonasi kawasan. Daerah yang disarankan dilakukan tindakan pengawasan memiliki luas sebesar 1.194,71 Ha atau 58,35 $\%$ dari total luas daerah penelitian. Wilayah ini sebagian besar terdapat di kawasan TNGM bagian selatan dekat dengan batas kawasan dimana masih memiliki pengaruh dari aktivitas masyarakat desa sekitar kawasan. 
DAFTAR PUSTAKA

Crisana, C.W. (2014). Analisis Perbandingan Metode Klasifikasi Autocorrelation Based Regioclassification (ACRC) Dan Non-ACRC Untuk Data Spasial. Skripsi. Departemen Ilmu Komputer, Fakultas Matematika dan Ilmu Pengetahuan Alam, Institut Pertanian Bogor.

Darmawan. (2016). Dampak Pemanfaatan Perumputan Oleh Masyarakat Desa Penyangga (Kasus Perumpuan di Resort Srumbung Taman Nasional Gunung Merapi). Tesis. Magister Ilmu Kehutanan, Sekolah Pascasarjana Universitas Gadjah Mada.

Djajono, A. (2009). Persoalan Sosial Ekonomi Seputar Kawasan Hutan "Perambahan Kawasan". Artikel daring. Diakses tanggal 22 Mei 2017.

Kompas, 2012. Taman Nasional Rusak Parah. Artikel daring. URL: http://tekno.kompas.com/read/2012/ 04/19/01422024/taman.nasional.rusak. parah. Diakses tanggal 5 Juni 2017.

Marhaento, H. dan Rahayu, L. (2015). Risiko Kepunahan Keanekaragaman Hayati di Taman Nasional Gunung Merapi: Tinjauan Spasial. Jurnal Ilmu Kehutanan. 9(2). 7584.
Mulyanto, L. dan Jaya, I. (2004). Analisis Spasial Degradasi Hutan Dan Deforestasi: Studi Kasus di PT. Duta Maju Timber, Sumatera Barat. Jurnal Manajemen Hutan Tropika. X(1). 29-42.

Purba, S.A. (2010). Pemodelan Spasial Tingat Kerawanan Konversi Lahan Hutan di Daerah Aliran Sungai (DAS) Deli Sumatra Utara. Skripsi. Departemen Kehutanan, Fakultas Pertanian Universitas Sumatra Utara.

Putikasari, V., Dahlan, E.N., dan Prasetyo, L.B. (2014). Analisis Perubahan Penutupan Lahan dan Faktor Sosial Ekonomi Penyebab Deforestasi di Cagar Alam Kamojang. Media Konservasi. 19(2). 126-140.

Rakhmawati, U. (2008). Pengelolaan Kawasan Taman Nasional Gunung Merapi Yang Berkelanjutan Dan Berbasis Masyarakat Dengan Kampanye Pride. Rencana Kerja. Yayasan Kanopi Indonesia.

Yuniarsih, A., Marsono, D., Pudyatmoko, S., dan Sadono, R. (2014). Zonasi Taman Nasional Gunung Ciremai Berdasarkan Sensitivitas Kawasan Dan Aktivitas Masyarakat. Jurnal Penelitian Hutan dan Konservasi Alam. 11(3). 239-259. 